\title{
Origin of the Polysaccharide Component of Ooze from Plants Infected with Erwinia amylovora
}

\author{
By ROBERT A. BENNETT*广 AND EVE BILLING \\ East Malling Research Station, Maidstone, Kent ME19 6BJ
}

(Received 21 May 1979)

\begin{abstract}
The composition of extracellular polysaccharides produced by Erwinia amylovora in defined culture media was compared with that of the polysaccharide present in the ooze produced during fireblight infection. The results strongly suggested that the ooze polysaccharide was of bacterial origin.

Two distinct polysaccharides were produced in vitro. One contained galactose (61 to $69 \%$ ), glucose ( 8 to $11 \%$ ), mannose ( 2 to $6 \%$ ) and uronic acid (16 to $23 \%$ ) and the other contained only fructose. Both the quantity and composition of the polysaccharide produced was determined by the nature and concentration of the sugar or sugar alcohol supplied and by the nature of the nitrogen source.

Evidence is also presented which suggests that production of the ooze-like polysaccharide is a virulence determinant and that this polysaccharide is similar in composition to the capsule. Preliminary studies indicate the presence of capsule and polysaccharide-hydrolysing enzymes in lysates of phage-infected bacteria.
\end{abstract}

\section{INTRODUCTION}

One of the commonest early symptoms of fireblight disease is the exudation of a gummy bacterial mass or ooze which appears as globules, or a spreading film or fine strands on the surface of infected plant tissues. Apart from bacteria, the ooze consists mainly of a high molecular weight polysaccharide composed of galactose $(74 \%)$, uronide $(16 \%)$ and small quantities of glucose and possibly mannose (Eden-Green \& Knee, 1974; Goodman et al., 1974). The origin and function of the polysaccharide constituent of the ooze are not clear. Eden-Green \& Knee (1974) extracted similar polysaccharides from bacteria grown on yeast extract peptone agar with added galactose, glucose or sorbitol. Beer et al. (1977) have also reported finding a similar polysaccharide in nutrient broth shake cultures of Erwinia amylovora. Goodman et al. (1974), however, failed to detect this polysaccharide in cultures of E. amylovora after $48 \mathrm{~h}$ growth in a defined liquid medium and suggested that the ooze polysaccharide was produced as a result of an interaction between the pathogen and a susceptible host.

The initial object of this study was to determine whether the ooze polysaccharide was of bacterial origin. Evidence is also presented which suggests that polysaccharide production is a virulence determinant, that the free extracellular polysaccharide is similar in composition to the capsule and that the nature and concentration of the carbon source affects the formation of both.

$\uparrow$ Present address: Agricultural Research Council, Letcombe Laboratory, Wantage OX12 9JT. 


\section{Table 1. Origin and yields of polysaccharides analysed}

Source of
polysaccharide

In vivo

Apple, pear or

hawthorn shoots

In vitro

ASP

$+1 \%$ sorbitol

$+1 \%$ sorbitol

$+1 \%$ glucose

$+1,5$ or $10 \%$ sucrose

+5 or $10 \%$ glucose

+5 or $10 \%$ sorbitol

ARJ

$+1,5$ or $10 \%$ glucose

$+1,5$ or $10 \%$ sorbitol

$+1,5$ or $10 \%$ sucrose
Pear fruit slices

\begin{tabular}{lc}
\multicolumn{1}{c}{ Strain* } & $\begin{array}{c}\text { Polysaccharide } \\
\text { yield }\end{array}$ \\
T & ++ \\
T, AT, E9 & ++ \\
& \\
T, AT, E9, P66 & ++ \\
P70, 4S1, 4S2 & \\
4L1, 3A2B, E8 & - \\
T & ++ \\
T & ++ \\
T & - \\
T & - \\
T & \\
T & - \\
T & \\
T &
\end{tabular}

METHODS

Cultures. Most of the cultures were from a collection at East Malling Research Station; these were virulent strains $\mathrm{T}$ and AT (a variant colony from $\mathrm{T}$ ) and avirulent strains 4S1, 4S2, 4L1 (phage-resistant mutants from T), P66, P70 and 3A2B. Two further cultures (one avirulent, E8, and one virulent, E9) were from Professor R. N. Goodman (Columbia University, Mo., U.S.A.).

Sources of polysaccharides. These were from three sources: infected shoots, infected immature pear fruit slices and supernatants from shake cultures grown in defined liquid media. With two hosts, two defined media, three carbon sources and several different strains of the organism it was impossible to examine the polysaccharides from all the possible combinations. Those selected were chosen to compare the polysaccharides produced by (1) a single strain in several hosts, (2) several strains in a single host, (3) a single strain in several media and (4) different strains in a single medium. Details of the hosts, media and strains used are shown in Table 1.

(i) Production in vivo. Ooze was collected from apple, pear and hawthorn shoots which had been inoculated with $E$. amylovora strain $\mathrm{T}$ and from immature 'Conference' pear fruits which had been inoculated with strains T, AT or E9. Bacteria were removed from aqueous solutions of the ooze (about $1 \%$, w/v) by centrifuging at $3750 \mathrm{~g}$ for $15 \mathrm{~min}$ followed by membrane filtration (Millipore filter, type $\mathrm{HA}, 0.45 \mu \mathrm{m}$ pore size).

(ii) Production in vitro. Eden-Green \& Knee (1974) extracted polysaccharides from bacterial masses grown on the surface of agar plates containing yeast extract and peptone with added galactose, glucose or sorbitol. Use of this method raised several problems as the yeast extract contained polysaccharides and the agar contained D-galactose and derivatives such as 6-methyl-D-galactose and galactose 6-sulphate. Although the risk of contamination of the bacterial polysaccharide may have been negligible it could not be ruled out. A suitable defined liquid medium was therefore sought for polysaccharide production.

The first medium chosen was that of Ayres et al. (1919), a mineral salts medium (ARJ) which contained $\left(\mathrm{g} \mathrm{l}^{-1}\right): \mathrm{NH}_{4} \mathrm{H}_{2} \mathrm{PO}_{4}, 1 \cdot 0 ; \mathrm{KCl}, 0 \cdot 2 ; \mathrm{MgSO}_{4} .7 \mathrm{H}_{2} \mathrm{O}, 0 \cdot 2 ;$ nicotinic acid, $0 \cdot 2 ;$ thiamin. $\mathrm{HCl}, 0 \cdot 2 ;$ Oxoid agar, 12. The second medium was an asparagine-based mineral medium (ASP) which contained $\left(\mathrm{g}^{-1}\right)$ : asparagine, $4 \cdot 0 ; \mathrm{K}_{2} \mathrm{HPO}_{4}, 2 \cdot 0 ; \mathrm{MgSO}_{4} \cdot 7 \mathrm{H}_{2} \mathrm{O}, 0 \cdot 2 ; \mathrm{NaCl}, 3 \cdot 0 ;$ nicotinic acid, $0 \cdot 2$; thiamin. $\mathrm{HCl}, 0 \cdot 2 ;$ Oxoid agar, 12. Filter-sterilized solutions of glucose, sucrose or sorbitol were added to a final concentration of 1,5 or $10 \%$ (w/v).

Polysaccharide was produced in $250 \mathrm{ml}$ conical flasks containing $50 \mathrm{ml}$ broth inoculated with about $5 \times 10^{7}$ cells of selected strains of $E$. amylovora grown overnight on yeast peptone agar slopes. Cultures were incubated at $25^{\circ} \mathrm{C}$ for $48 \mathrm{~h}$ in a Mk 6 rotary shaker incubator (L.H. Engineering, Stoke Poges, Bucks.) at 100 cycles $\mathrm{min}^{-1}$. A $2 \mathrm{~cm}$ diameter stainless steel coil spring was positioned around the inside of the flask to aid aeration during incubation. Bacteria were removed from the culture fluids as described above.

(iii) Extraction. Before extraction of the polysaccharides, the bacteria-free samples were concentrated to a 
final volume of about 10 to $15 \mathrm{ml}$ on a rotary evaporator at $30^{\circ} \mathrm{C}$ and then dialysed (Visking tubing 3/32) against $2 \times 11$ distilled water at $4{ }^{\circ} \mathrm{C}$ for $48 \mathrm{~h}$. Ethanol was then added (final concn $80 \%, \mathrm{v} / \mathrm{v}$ ) and the polysaccharide was precipitated by adding a few drops of saturated $\mathrm{CaCl}_{2}$ solution. After centrifuging $(1500 \mathrm{~g}$, $10 \mathrm{~min}$ ), the polysaccharide pellet was washed three times in absolute ethanol, dried and stored in vacuo over $\mathrm{P}_{2} \mathrm{O}_{5}$. No attempt was made to purify the polysaccharides further at this stage.

Comparison of polysaccharides.

(i) Infrared spectroscopy. Samples were dispersed in $\mathrm{KBr}$ discs at a concentration of about $2 \mathrm{mg}$ per $200 \mathrm{mg} \mathrm{KBr}$ and spectra were obtained using a Unicam SP1200 infrared spectrophotometer.

(ii) Descending paper chromatography. Polysaccharide ( $2 \mathrm{mg})$ was heated in a boiling water bath for $40 \mathrm{~min}$ with $0.2 \mathrm{ml} 2 \mathrm{M}-\mathrm{HCl}$. The solution was evaporated to dryness on a rotary evaporator at $40^{\circ} \mathrm{C}$; the dried sample was redissolved in $1 \mathrm{ml}$ distilled water and re-evaporated. This process was repeated twice more. The dried solid was finally redissolved in $10 \%$ (v/v) aqueous propan-2-ol for chromatography. Samples ( 3 or $6 \mu \mathrm{l})$ of the hydrolysates were spotted on to Whatman no. 1 paper $(48 \times 21 \mathrm{~cm})$ and descending chromatograms were developed for $24 \mathrm{~h}$ using, as solvent, either methyl ethyl ketone/saturated aqueous boric acid/ glacial acetic acid (MEK, 9:1:1, by vol.) or butan-1-ol/pyridine/water (BPW, 6:4:3, by vol.). The chromatograms were then dried and the spots were visualized either by dipping the chromatograms in 4-aminobenzoic acid reagent (Saini, 1966) and heating at $105^{\circ} \mathrm{C}$ for 10 to $15 \mathrm{~min}$ or by dipping them in $\mathrm{AgNO}_{3}$ solution followed by $\mathrm{NaOH}$ and $\mathrm{Na}_{2} \mathrm{~S}_{2} \mathrm{O}_{3}$. The latter is a modification of the method of Trevelyan et al. (1950) in which excess $\mathrm{Ag}_{2} \mathrm{O}$ was removed using $6 \mathrm{M}-\mathrm{NH}_{4} \mathrm{OH}$.

(iii) Paper electrophoresis. Polysaccharide hydrolysate solutions were also subjected to paper electrophoresis. Electrophoretograms were developed on Whatman no. 1 paper in sodium phosphate buffer $(0 \cdot 1 \mathrm{M}$, $\mathrm{pH} 8.5$ ) for $90 \mathrm{~min}$ at about $30 \mathrm{~V} \mathrm{~cm}^{-1}$. After drying, the spots were visualized as described above.

(iv) Gas-liquid chromatography. Hydrolysis and preparation of volatile sugar acetates was done by the method of Holligan \& Drew (1971). The acetate derivatives were separated using a Pye series 104 chromatograph with a flame ionization detector. The oven temperature was $225^{\circ} \mathrm{C}$ and $1 \mu \mathrm{l}$ samples were injected at $300{ }^{\circ} \mathrm{C}$ into a $1.7 \mathrm{~m} \times 4 \mathrm{~mm}$ column of $5 \%$ silicone OV-275 on Chromosorb W (100 to 120 mesh) fed with $\mathrm{N}_{2}$ carrier gas at $40 \mathrm{ml} \mathrm{min}{ }^{-1}$. Peaks were eluted and detected isothermally at $275^{\circ} \mathrm{C}$.

(v) Estimation of uronide content. This was done using the method of McCready \& McComb (1952).

(vi) Gel-filtration on Sepharose 2B. Eden-Green \& Knee (1974) reported that the polysaccharide found in ooze was eluted from a Sephadex G-200 column in the void volume, suggesting a molecular weight in excess of 200000. To obtain a more accurate idea of the molecular weight of this and the other polysaccharides, Sepharose 2B was used, as this has a separation range for globular proteins of between 500000 and 25000000 . Fractionation was done at room temperature on a column $(37 \times 1.8 \mathrm{~cm}$, void volume $30 \mathrm{ml}$, bed volume $90 \mathrm{ml})$ equilibrated with $0.4 \%(\mathrm{v} / \mathrm{v})$ aqueous pyridine buffer adjusted to $\mathrm{pH} 5.4$ with glacial acetic acid. The height of the column reservoir was adjusted to give a working pressure head of $30 \mathrm{~cm}$ and a flow rate of about $25 \mathrm{ml} \mathrm{h}^{-1}$. Samples $(1 \mathrm{ml})$ containing $2.5 \mathrm{mg}$ polysaccharide were loaded on to the column and fractions were collected automatically every $5 \mathrm{~min}$ over a $5 \mathrm{~h}$ period. Eluate samples were analysed for the presence of carbohydrate by adding $0.5 \mathrm{ml} 5 \%(\mathrm{w} / \mathrm{v})$ aqueous phenol solution to $1 \mathrm{ml}$ sample, then quickly adding $2.5 \mathrm{ml}$ conc. $\mathrm{H}_{2} \mathrm{SO}_{4}$ so that the mixture boiled. After cooling, the mixture was incubated at $25^{\circ} \mathrm{C}$ for $10 \mathrm{~min}$ to allow for colour development and the $A_{485}$ of the samples was measured on a Unicam SP800 u.v. spectrophotometer.

(vii) Electrophoresis on cellulose acetate. Unhydrolysed polysaccharides were subjected to cellulose acetate electrophoresis in $0.1 \mathrm{M}$-sodium acetate buffer $\mathrm{pH} 6.7$ for $10 \mathrm{~min}$ at $15 \mathrm{~V} \mathrm{~cm}^{-1}$. The polysaccharides were visualized by dipping the cellulose strips in toluidine blue for $3 \mathrm{~min}$ and then washing in $80 \%(\mathrm{v} / \mathrm{v})$ aqueous ethanol until most of the background stain was removed.

(viii) Polysaccharide-hydrolysing enzyme in crude phage $\mathrm{L} 3 \mathrm{H}$ preparations. Three phages $(4 \mathrm{~S}, 4 \mathrm{~L}, \mathrm{~L} 3 \mathrm{H})$ produced haloes of reduced turbidity around their plaques on capsulated cultures. Billing (1960) suggested that these haloes might be caused by a capsule-hydrolysing enzyme. Some evidence supporting this idea has been described (Bennett, 1978a). If the loosely bound extracellular polysaccharides produced by $E$. amylovora are the same or very similar to the capsular material, such enzymes could be useful tools in helping to characterize these compounds. An attempt was made to determine whether extracellular polysaccharidehydrolysing enzymes were present in crude phage $\mathrm{L} 3 \mathrm{H}$ preparations (CPP).

A $10 \mathrm{ml}$ portion of $\mathrm{L} 3 \mathrm{H}$ phage suspension containing about $1 \times 10^{8}$ plaque-forming units $\mathrm{ml}^{-1}$ was added to $10 \mathrm{ml}$ of a broth shake culture [which contained $\left(\mathrm{g}^{-1}\right)$ : yeast extract, 3 ; peptone, 5 ; glycerol, 10] of strain T containing about $1 \times 10^{8}$ cells $\mathrm{ml}^{-1}$. After $6 \mathrm{~h}$ incubation at $25^{\circ} \mathrm{C}$ in a Mk 6 rotary shaker incubator (L.H. Engineering), the mixture was centrifuged at $3750 \mathrm{~g}$ for $15 \mathrm{~min}$ followed by membrane filtration to remove any remaining bacteria. The $20 \mathrm{ml} \mathrm{CPP}$ was then concentrated to $5 \mathrm{ml}$ on a rotary evaporator at $30^{\circ} \mathrm{C}$.

Polysaccharides from broth shake culture (ASP $+1 \%$ sorbitol) of strain $\mathrm{T}$ and from pear slice ooze (strain T) were used in these experiments. To determine whether degradative activity was present, the CPP 


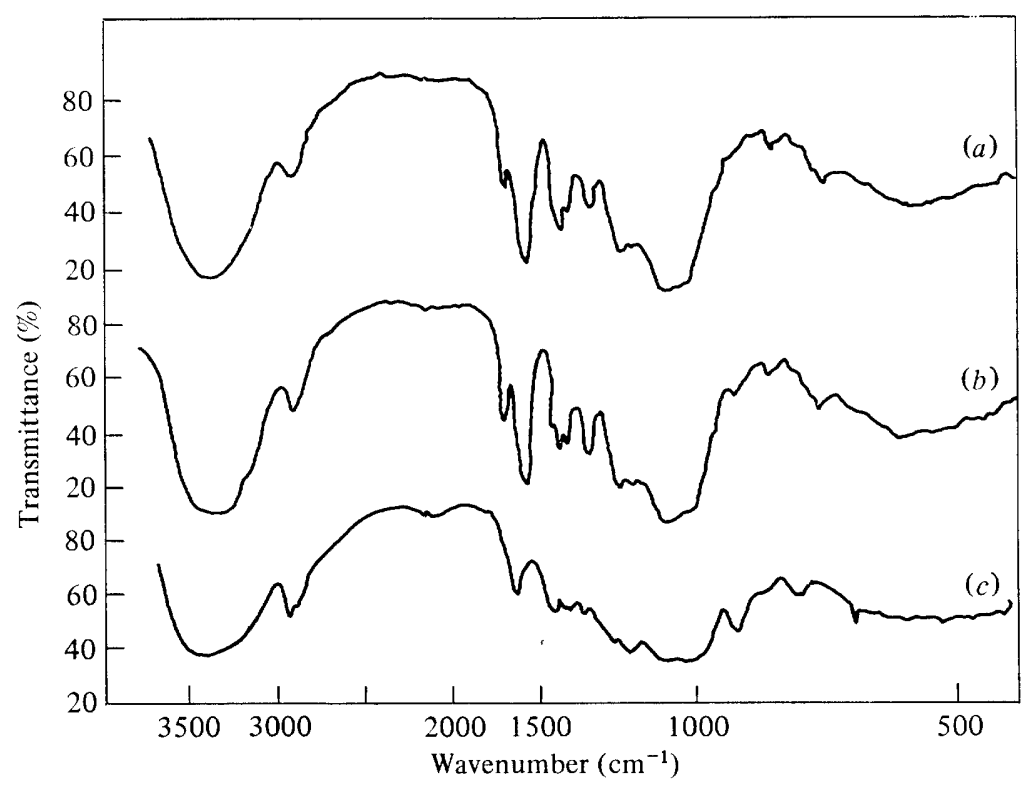

Fig. 1. Infrared spectra of polysaccharides produced by Erwinia amylovora strain T: (a) polysaccharide from pear slice ooze; $(b)$ polysaccharide from ASP $+1 \%$ sorbitol; $(c)$ polysaccharide from ASP $+10 \%$ sucrose.

was mixed in equal proportions with aqueous polysaccharide solutions $\left(10 \mathrm{mg} \mathrm{m}^{-1}\right)$ and incubated in a water bath at $25^{\circ} \mathrm{C}$ for $5 \mathrm{~h}$. The incubated solutions were analysed for changes in viscosity, behaviour on gel-filtration with Sepharose 2B and composition determined by descending paper chromatography and paper electrophoresis. Viscosity was measured using an Ostwald viscometer (capacity $1.3 \mathrm{ml}$ ), immersed in water at $20^{\circ} \mathrm{C}$. Measurements were taken at $5 \mathrm{~min}$ intervals for the first $30 \mathrm{~min}$ and then at $30 \mathrm{~min}$ intervals for the next $4.5 \mathrm{~h}$. Controls were polysaccharide alone and polysaccharide plus heat-treated $\left(80^{\circ} \mathrm{C}\right.$ for 10 $\min ) \mathrm{CPP}$.

\section{RESULTS}

\section{Comparison of polysaccharides}

Infrared spectroscopy. Examples of the spectra from different polysaccharides are shown in Fig. 1. The spectra of polysaccharides produced in vivo were the same irrespective of their origin and have been labelled as type 1 . The polysaccharides produced by strains T, AT, E9 and $\mathrm{P} 66$ in the ASP $+1 \%$ sorbitol or by strain T in ASP $+1 \%$ glucose or sucrose, also gave the type 1 spectrum. However, the polysaccharides produced by strain T in ASP +5 or $10 \%$ sucrose or in ARJ $+1,5$ or $10 \%$ sucrose showed a different spectrum (type 2). Neither of the spectra produced by the E. amylovora polysaccharides appeared to be the same as those produced by the known polysaccharides inulin, starch or dextran.

Paper chromatography. The results are summarized in Table 2 and show the components of each polysaccharide. All the polysaccharides produced in vivo and those produced by strains T, AT, E9 and P66 in ASP $+1 \%$ sorbitol and by strain T in ASP $+1 \%$ glucose or sucrose were similar and contained mainly galactose with smaller quantities of glucose and two unidentified compounds. The unidentified compounds had similar $R_{F}$ values to galacturonic and glucuronic acid when developed in the BPW solvent, but in the MEK solvent the unknowns remained close to the origin whereas the uronic acids had the same $R_{F}$ values as glucose and galactose. The two unknown compounds also stained differently from the uronic acids with the 4-aminobenzoic acid reagent: the neutral hexose sugars and the unknowns stained orange/brown whereas the uronic acids stained pink. As the uronic acid standards had the same $R_{F}$ value in BPW as the unknowns and the same $R_{F}$ value in MEK 
Table 2. Paper chromatographic analysis of acid hydrolysates of polysaccharides produced by Erwinia amylovora

\begin{tabular}{|c|c|c|}
\hline $\begin{array}{c}\text { Source of } \\
\text { polysaccharide }\end{array}$ & Strain & $\begin{array}{l}\text { Components in } \\
\text { hydrolysates } \\
\text { (in order of spot d }\end{array}$ \\
\hline $\begin{array}{l}\text { In vivo } \\
\text { Apple, pear and } \\
\text { hawthorn shoots }\end{array}$ & $\mathrm{T}$ & \multirow{3}{*}{$\begin{array}{l}\text { Galactose } \\
\text { Unknown } 1 \\
\text { Unknown } 2 \\
\text { Glucose }\end{array}$} \\
\hline Pear fruit slices & $\mathrm{T}, \mathrm{AT}, \mathrm{E} 9$ & \\
\hline $\begin{array}{l}\text { In vitro* } \\
\text { ASP } \\
+1 \% \text { sorbitol } \\
+1 \% \text { glucose } \\
+1 \% \text { sucrose }\end{array}$ & $\begin{array}{l}\mathrm{T}, \mathrm{AT}, \mathrm{E} 9, \mathrm{P} 66 \\
\mathrm{~T} \\
\mathrm{~T}\end{array}$ & \\
\hline $\begin{array}{l}\text { ASP } \\
+5 \text { or } 10 \% \text { sucrose }\end{array}$ & $\mathrm{T}$ & \multirow{2}{*}{ Fructose } \\
\hline $\begin{array}{l}\text { ARJ } \\
+1,5 \text { or } 10 \% \text { sucrose }\end{array}$ & $\mathrm{T}$ & \\
\hline
\end{tabular}

as the neutral sugars, it was not possible to say whether or not free galacturonic or glucuronic acids were present in the hydrolysates.

The polysaccharides produced by strain T in ASP +5 or $10 \%$ sucrose and ARJ $+1,5$ or $10 \%$ sucrose contained only fructose and might possibly be levan.

Paper electrophoresis. The polysaccharides produced in vivo and those produced by strains T, AT, E9 and P66 in ASP $+1 \%$ sorbitol and by strain T in ASP $+1 \%$ glucose or sucrose, all contained traces of glucuronic acid and two unidentified compounds both of which had fairly high electrophoretic mobilities (though not as high as the uronic acids) and migrated towards the positive electrode which showed them to be acidic. The levan-like polysaccharide from the other sucrose media remained at the origin of the electrophoretogram.

Gas-liquid chromatography and uronide content. The results of the tests described above show that E. amylovora is capable of producing at least two polysaccharides in vitro and suggest that one of these is the same as that found in ooze. To test this further, the polysaccharides from pear slice ooze (strain T), ASP $+1 \%$ sucrose or glucose (strain T) and ASP $+1 \%$ sorbitol (strains T, AT and P66) were analysed by gas-liquid chromatography. All six polysaccharides contained galactose, glucose and small quantities of mannose and some minor components of uncertain identity. Details of the results, expressed as a percentage of the total hexose positively identified, are shown in Table 3 . These six polysaccharides also contained between 16 and $23 \%$ uronide (Table 3 ).

Column chromatography on Sepharose $2 B$. Gel-filtration was done on the polysaccharides from pear slice ooze (strain T) and ASP $+1 \%$ sorbitol (strains T, AT, P66). All four polysaccharides were just retained by the gel and appeared as a single peak $5 \mathrm{ml}$ after the void volume. This suggests they have a very high molecular weight. Although these results do not give an accurate molecular weight determination, they do show that the polysaccharides produced in vivo and in vitro are comparable in size.

Cellulose acetate electrophoresis. The polysaccharides listed above all migrated as a single peak the same distance towards the positive electrode, showing that their mass/charge ratios are similar and that they are all acidic.

Degradative activity in crude phage $\mathrm{L} 3 \mathrm{H}$ preparations. The polysaccharides from both the pear slice ooze and the broth shake culture gave the same results in the following experiments.

Viscosity. After incubation with CPP, the polysaccharides showed a rapid and marked drop in viscosity (Fig. 2). However, no such change was observed when the polysaccharides 
Table 3. Composition of polysaccharides produced by Erwinia amylovora

Source of polysaccharide

In vivo

Pear slice ooze

In vitro

ASP +

$+1 \%$ glucose

$+1 \%$ sucrose

$+1 \%$ sorbitol

$+1 \%$ sorbitol

$+1 \%$ sorbitol

Percentage composition*

$\begin{array}{lcrcc}\text { Strain } & \text { Galactose } & \text { Glucose } & \text { Mannose } & \text { Uronide } \\ \mathrm{T} & 73.3 & 7.0 & 3.4 & 16.3 \\ & & & & \\ \mathrm{~T} & 61.6 & 10.8 & 4.9 & 22.7 \\ \mathrm{~T} & 69.3 & 9.4 & 4.6 & 16.7 \\ \mathrm{~T} & 67.7 & 8.5 & 2.3 & 21.5 \\ \mathrm{AT} & 65.0 & 10.8 & 1.5 & 22.7 \\ \text { P66 } & 64.3 & 8.1 & 6.0 & 21.6\end{array}$

* Hexoses were determined by gas-liquid chromatographic analysis of acid hydrolysates; uronides were estimated by a colorimetric method (McCready \& McComb, 1952).

$\uparrow$ ASP, Asparagine salts medium.

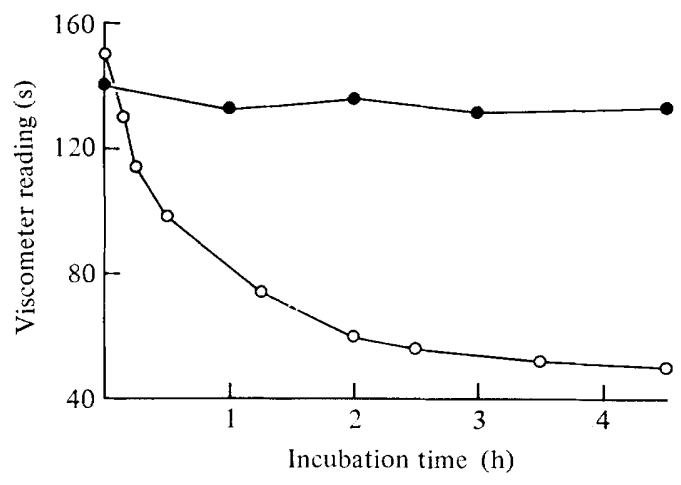

Fig. 2. Viscosity measurements of the ooze polysaccharide before $(O)$ and after $(O)$ the addition of phage $\mathrm{L} 3 \mathrm{H}$ preparation.

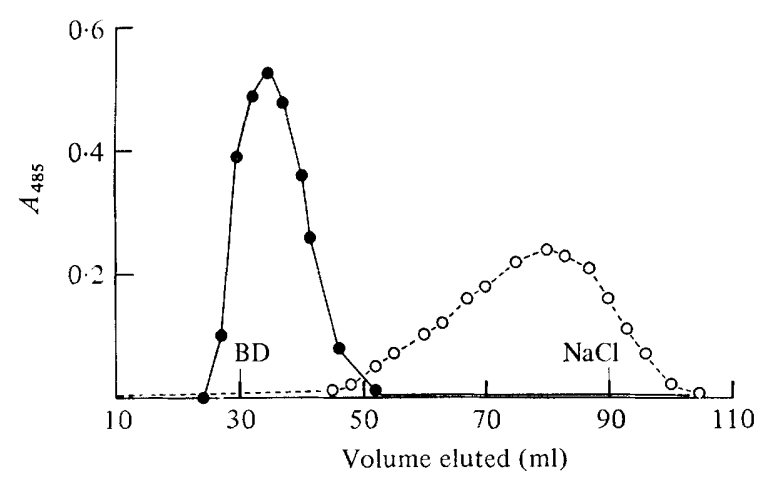

Fig. 3. Behaviour of polysaccharide from ooze on Sepharose 2B gel-filtration before (O) and after (O) incubation with phage $\mathrm{L} 3 \mathrm{H}$ preparation. The elution volumes of Blue dextran (BD) and $\mathrm{NaCl}$ are shown. 
were incubated with heat-treated CPP or alone. This shows that CPP contains heat-labile polysaccharide-degrading activity.

Behaviour on gel-filtration. Prior to incubation with CPP and after incubation with heattreated CPP, the polysaccharides were eluted as a single peak just after the void volume. However, after incubation with CPP, a mixed population of lower molecular weight oligosaccharides were eluted as a broad peak near the bed volume for the column (Fig. 3).

Descending paper chromatography and paper electrophoresis. Irrespective of treatment, both polysaccharides remained at the origin of the chromatograms and electrophoretograms showing that simple sugar compounds had not been released.

\section{DISCUSSION}

The results strongly suggest that in certain defined culture media, E. amylovora produces the same polysaccharide as that found in ooze. The polysaccharides produced by a single strain of the organism in different hosts and by different strains in the same host all appeared to be similar. These findings support and extend those of Eden-Green (1972), Eden-Green \& Knee (1974) and Beer et al. (1977).

Both the quantity and composition of the polysaccharides produced in vitro were affected by the nature and concentration of the sugar or sugar alcohol supplied and by the nature of the nitrogen source; capsulation is also affected in the same way (Bennett \& Billing, 1978a). Large quantities of ooze-like polysaccharide were produced by strain $\mathrm{T}$ in the asparaginebased medium (ASP) supplemented with $1 \%$ glucose, sucrose or sorbitol, but if the concentration of glucose or sorbitol was increased to 5 or $10 \%$, polysaccharide production was completely suppressed. When the concentration of sucrose was increased to 5 or $10 \%$, however, polysaccharide production was still high but the polysaccharide produced contained only fructose.

In the ammonium-based medium (ARJ), no polysaccharide was produced when glucose or sorbitol were supplied as the carbon source, though in the presence of sucrose, small quantities of the fructose polysaccharide were produced. This agrees with the findings of Goodman et al. (1974) who were unable to isolate ooze-like polysaccharide from E. amylovora cultures grown in defined inorganic media for $48 \mathrm{~h}$.

All three virulent strains and the capsulated avirulent strain P66 produced the ooze-like polysaccharide in ASP $+1 \%$ sorbitol. In contrast, no polysaccharide was produced in this medium by any of the non-capsulated avirulent strains. This suggests that production of the ooze-like polysaccharide, as well as capsulation (Bennett \& Billing, 1978a), is associated with virulence. The fact that strain P66 is capsulated and produces the ooze-like polysaccharide in vitro, but is avirulent, shows that at least one other factor is involved in virulence. Evidence supporting this idea is reported elsewhere (Bennett, 1978 $a, b$; Bennett \& Billing, 1978b; Bennett, 1980).

In histological studies, several workers (Nixon, 1927; Haber, 1928; Miller, 1929) observed that the bacteria in host tissue were embedded in a gelatinous matrix within $10 \mathrm{~h}$ of inoculation. This suggests that extracellular polysaccharide is present during the early stages of infection but its role (if any) has not yet been determined.

It has been postulated, on the basis of cut shoot and petiole wilt induction tests, that the ooze polysaccharide (amylovorin) is a host-specific toxin (Goodman et al., 1974, 1978; Hsu \& Goodman, 1978). These authors suggested that the polysaccharide might be used to evaluate varietal resistance of apple and pear to the fireblight bacterium, but Beer \& Aldwinckle (1976) were unable to confirm this with shoots of apple cultivars and so far success has not been reported from other laboratories. Furthermore, Sjulin \& Beer (1978) in experiments with Cotoneaster concluded that the polysaccharide induced wilt of cut shoots by restriction of water movement rather than by the direct toxic effect suggested by Huang \& Goodman (1976); they observed no detrimental effect of the polysaccharide on 
host cells that could account for the wilting observed by various workers during the early stages of infection.

So far, capsulation has always been associated with ooze-like polysaccharide production. How closely the bound capsular material resembles the free polysaccharide is uncertain, but there is now evidence which suggests that they are very similar in composition. Lysates from bacteria infected with phages $4 \mathrm{~S}, 4 \mathrm{~L}$ and $\mathrm{L} 3 \mathrm{H}$ appear to contain capsule-hydrolysing enzymes while those from bacteria infected with phage L3H (and possibly $4 \mathrm{~S}$ and $4 \mathrm{~L}$ ) possess heat-labile polysaccharide-degrading ability. Further work using purified enzymes from phage lysates could help to characterize these compounds.

There are conflicting views about the importance of the sugar concentration in nectar in relation to the susceptibility of pear and apple blossom to fireblight (Schroth et al., 1974). Apart from the effect of sugar concentration on the growth of the pathogen, Thomas \& Ark (1934) reported that cultures of E. amylovora grown in the presence of high concentrations of sugar were weakened in virulence. Furthermore, virulence could be restored by growth in media containing 1 to $2 \%$ sugar. Ivanoff \& Keitt (1941) found, during experiments using contaminated bees to transmit the disease from one blossom to another, that there were many cases in which the nectar was at a favourable concentration for bacterial growth but no infection occurred. The work reported here suggests one possible explanation for these observations which merits further study, i.e. that capsule and polysaccharide production are suppressed by sugar concentrations which are not sufficient to inhibit growth and that this results in a reduction in the virulence of the organism.

Note added in proof. After completion of this work, Slade \& Tiffin (1978) showed, using serological techniques, that E. amylovora produced the same exopolysaccharide in vivo and in vitro, both as a capsule and an extracellular slime.

We are grateful to R. C. Hignett for help and advice. One of us (R. A. Bennett) was supported by an Agricultural Research Council Grant.

\section{REFERENCES}

Ayres, S. H., Rupp, P. \& Johnson, W. T. (1919). A study of the alkali-forming bacteria in milk. United States Department of Agriculture Bulletin no. 782 .

Beer, S. V. \& Aldwinckle, H. S. (1976). Lack of correlation between susceptibility to Erwinia amylovora and sensitivity to amylovorin in apple cultivars. Proceedings of the American Phytopathological Society 3, 300 (abstract).

Beer, S. V., Baker, C. J., Woods, A. C. \& Suulin, T. M. (1977). Amylovorin production in vitro and partial characterisation. Proceedings of the American Phytopathological Society 4, 182-183 (abstract).

BENNETT, R. A. (1978a). Characteristics of the fireblight pathogen in relation to virulence. Ph.D. thesis, University of London.

BenNetT, R. A. (1978b). Characteristics of Erwinia amylovora in relation to virulence. Proceedings of the IVth International Conference on Plant Pathogenic Bacteria, vol. II, pp. 479-481.

BENNETT, R. A. (1980). Evidence for two virulence determinants in the fireblight pathogen Erwinia amylovora. Journal of General Microbiology 116, 351-356.

BennetT, R. A. \& Billing, E. (1978a). Capsulation and virulence in Erwinia amylovora. Annals of Applied Biology 89, 41-45.
Bennett, R. A. \& Billing, E. (1978b). Investigations on virulence determinants of Erwinia amylovora. Proceedings of the IIIrd International Congress of Plant Pathology, p. 69 (abstract).

Billing, E. (1960). An association between capsulation and phage sensitivity in Erwinia amylovora. Nature, London 186, 819-820.

EdEN-Green, S. J. (1972). Studies in fireblight disease of apple, pear and hawthorn (Erwinia amylovora (Burrill) Winslow et al.). Ph.D. thesis, University of London.

EDEn-Green, S. J. \& KNEE, M. (1974). Bacterial polysaccharide in fireblight exudate. Journal of General Microbiology 81, 509-512.

Goodman, R. N., Huang, J.-S. \& Huang, P.-Y. (1974). Host-specific phytotoxic polysaccharide from apple tissue infected by Erwinia amylovora. Science 183, 1081-1082.

Goodman, R. N., Stoffl, P. R. \& Ayers, S. M. (1978). The utility of the fireblight toxin, amylovorin, for the detection of resistance of apple, pear and quince to Erwinia amylovora. Acta horticulturae 86, 51-56.

HABER, J. M. (1928). The relationship between Bacillus amylovorus and leaf tissue of apple. Pennsylvania Agricultural Experimental Station Bulletin no. 228, 3-15.

Holligan, P. M. \& Drew, E. A. (1971). Routine 
analysis by gas-liquid chromatography of soluble carbohydrates in extracts of plant tissue. New Phytologist 70, 271-279.

Hsu, S.-T. \& Goodman, R. N. (1978). Production of a host-specific, wilt inducing toxin in apple cell suspension cultures inoculated with Erwinia amylovora. Phytopathology 68, 351-354.

Huang, P.-Y. \& Goodman, R. N. (1976). Uitrastructural modifications in apple stems induced by Erwinia amylovora and the fireblight toxin. Phytopathology 66, 269-276.

IVANOFF, S. S. \& KeITT, G. W. (1941). Relations of nectar concentration to growth of Erwinia amylovora and fireblight infection of apple and pear blossoms. Journal of Agricultural Research 62 , 733-743.

McCready, R. M. \& McComb, E. A. (1952). Extraction and determination of total pectic materials in fruits. Analytical Chemistry 24, 19861988.

Miller, P. W. (1929). Studies of fireblight of apple in Wisconsin. Journal of Agricultural Research 39, 579-621.

Nixon, E. L. (1927). The migration of Bacillus amylovorus in apple tissue and its effects on the host cells. Pennsylvania Agricultural Experimental Station Bulletin no. 212, 3-16.

SAINI, A.S. (1966). Technical improvements in paper chromatography of sugars: method of sample desalting and sensitive staining reagent. Journal of Chromatography 24, 484-486.

Schroth, M. N., Thompson, S. V., Hildebrand, D. C. \& Moller, W. J. (1974). Epidemiology and control of fireblight. Annual Review of Phytopathology 12, 389-412.

SJulin, T. M. \& BeER, S. V. (1978). Mechanism of wilt induction by amylovorin in cotoneaster shoots and its relation to wilting of shoots infected by Erwinia amylovora. Phytopathology 68, 89-94.

Slade, M. B. \& Tiffin, A. I. (1978). Serological cross-reactions between Erwinia amylovora and Erwinia herbicola. Proceedings of the IVth International Conference on Plant Pathogenic Bacteria, vol. I, pp. 289-294.

Thomas, H. E. \& Ark, P. A. (1934). Nectar and rain in relation to fireblight. Phytopathology 24, $682-685$

Trevelyan, W. E., Procter, D. P. \& Harrison, J.S. (1950). Detection of sugars on paper chromatograms. Nature, London 166, 444-445. 